\title{
HARNEY AND ENGELS
}

The English Chartists of the nineteenth century were men who lived in very modest circumstances, and their mobility, their empiricism, their lack of filing facilities, the housepride of their wives and the discontinuity of their particular organisations militated against the proper preservations of their archives. For the history of Chartism we rely upon contemporary printed sources, Home Office Papers, a handful of Collections and a few autobiographies. Thus when A.R. Schoyen set out to write Chartist Challenge, book a centred round the person of the Chartist leader George Julian Harney, he was obliged to open his Preface as follows: "The impersonal nature of most of the available materials on Julian Harney, mainly newspapers and periodicals in which he wrote, leave one with no more than conjectures about some aspects of his life."1

Since the publication of Schoyen's book in 1958 , however, the situation has very substantially improved. The Marx-Engels archives in Amsterdam have yielded I Io letters Harney wrote to Frederick Engels over the years from 1849 to 1895 and a quantity of other valuable Chartist material. Furthermore some of the papers that Harney left in America are now known to be in the possession of

\footnotetext{
${ }^{1}$ A. R. Schoyen, Chartist Challenge (London 1958). This book has added a new dimension to the study of Chartism. It provides the essential background to the new material presented here. The English Chartists constituted the first large independent working class political association in the world. They took their name from their six-point Charter adopted in May I838. The Six Points were - universal suffrage; the secret ballot; the abolition of property qualifications for MPs; equal electoral districts; annual Parliaments; the payment of Members. Chartist incentive arose from extreme dissatisfaction with the Great Reform Bill of $1_{32}$, a Bill that had been campaigned for by Political Unions of the Middle and Working Classes but from which "the working classes" got little or nothing beyond the new servitude of the 1834 Poor Law and the continuation of the "taxes on knowledge". (By 1836 the nineteen year old Harney had been to prison three times for selling unstamped or otherwise illegal radical newspapers.) The Six Points in various combinations and with varying degrees of emphasis had been actively canvassed since the 1770 s and the Great Reform Bill of 1832 was one outcome of that agitation. By that Bill the English middle class got its foot in the door of political power (at the expense of the prevailing landed aristoctacy) and the advocates of working class political emancipation had cause to think again about the intentions of their erstwhile political friends. The three periods of great Chartist activity were I $838-39$, I 842 and 1848 .
} 
Professor Frank Gees Black of the University of Oregon. Unfortunately Engels' replies to Harney are not amongst them. ${ }^{1}$ The purpose of this study is the publication of the essentials of the Amsterdam archives.

Harney and Engels met for the first time in 1843 . Harney, aged 26, was then sub-editor of the Chartist paper the Nortbern Star. Engels, aged 23, was collecting material for his book "The Condition of the Working Class in England". He went to Leeds to see Harney. Years later, in May 1887, when Harney was living in Cambridge, Massachusetts, Engels sent him the latest edition of that book. Harney read the new preface and appendix and wrote:

"The body of your book will be surely read, for it will bring back to me the stirring times when our friendship began; and I can see is brimful of the information of which our Chartist[s] James Leach and John West were the able, honest exponents."2

Their friendship lasted altogether for 52 years until the death of Engels in 1895 . There are no surviving letters in respect of the following periods: January 25 th 185 I to January 14 th 1858 ; May 5 th 1858 to April IIth I 876 ; March I 7 th I 883 to January 23 rd I 885 , but there is nothing to indicate that the two men were not corresponding in these periods although the first of them was certainly a time of political coolness.

The first letter in the collection is one written by Harney to Engels on March 19th 1849. It concerns his struggle with Feargus O'Connor, the founder of the Northern Star. Harney had been its editor since I 845 (the paper had moved to London in November '44) and his differences with O'Connor had become acute. On September 22nd r845 Harney had founded the Fraternal Democrats at a banquet held to celebrate the French Republic's constitution of $179^{2}$. Through this organisation, that anticipated the First International of twenty years later, Harney became steeped in the thinking and organisation of the international revolutionary movement. The Jacobin had become an international social-democrat. O'Connor on the other hand had remained strictly insular in his outlook, had no time for the new socialist ideas and had staked almost

\footnotetext{
${ }^{1}$ Professor Black has sent me a list of the letters in his possession. He writes: "The papers we have are those left by Harney in his widow's possession and given me by his stepson, my father-in-law." Letter of 3oth March i 964.

${ }^{2}$ Marx-Engels Archives, Internationaal Instituut voor Sociale Geschiedenis, Amsterdam; catalogued L IV 207.
} 
everything on his disastrous back-to-the-land scheme. He and Harney polarised the two opposing schools of thought in the Chartism of I 849. The letter reads:

"The sight of your handwriting after your long silence was a treat. Even if I had not had a letter from you, I should have written to you. Many thanks, heartfelt thanks for your translation (I mean by yours the Editors of the Gazette - Marx yourself etc etc) of my letter to $\mathrm{O}^{\prime} \mathrm{C}$. or rather, in reply to $\mathrm{O}^{\prime} \mathrm{C}$.'s villainous denunciations of our principles. I say 'our principles' for his denunciations were levelled against more than Republicanism - against every principle we hold dear. The fact is he is a thorough aristocrat masquerading in the outward profession of democracy. More still, he is worse than an aristocrat, he has all the vulgarism, the money grubbing (in spite of his boasting to the contrary) of a dirty bourgeois. But I believe the hour of his fall is at hand. I have not sought this quarrel, but as it is forced upon me I will not forget Polonius's advice to Laertes ('Hamlet'),

'Beware a quarrel,

But being in it, make thy opponent beware of thee.'

You will have seen his reply. Do not fear but I will answer all his lies and confound him out of his own mouth. But I expect my answer will be forcibly excluded from the Star. In that case I must have recourse to a pamphlet a copy of which I will send to you. Do not fear that I will succumbe [sic]. He shall publicly retract and apologise, and do me more justice than even that or I will wage war with him to the death, and pursue him to the gates of Hell. This is the beginning of the end of a Revolution in the Chartist Movement.

The feeling in my favour in London, and letters from the country afford me great encouragement. This morning I have received a letter from three of the Kirkdale prisoners - James Leach, John West and Geo. White, imploring me to stand firm and save our cause. They offer me their names, they will write for me, they will do anything for me I wish. They cry that the hour has struck when the great, worst enemy of our cause must be overthrown. I will not disappoint them.

My design is a new paper forthwith [...] unstamped twopenny, 8 pages, four columns to a page $[. .$.$] if successful get it made a$ stamped paper, $[\ldots]$ and add four, or eight pages.

I want your assistance. I want the paper to be not merely Chartist - I want it to be the organ of European Democracy. I want you to write a letter every week. If the paper is unstamped you cannot send news, but what you can send I will tell your hereafter. 
My fraternal regards to Marx, Weerth, Schapper and all friends." Nine days later he writes to record an unexpected victory:

"On Wednesday last I received an intimation from him [O'Connor, P.C.] that he had instructed the printer to give my manuscript to him before commencing to put it into type. On this I immediately wrote him a letter which he will not very soon forget. I told him that I would resent and resist any attempt either on the part of himself or his printer to establish a censorship over me; and that if he excluded me from the Star I would appeal to the people. I said much more in the language of very defiance. I made up my mind that that letter would ensure my dismissal. But not so. Judge of my surprise when next day he sent me a letter assuring me that he had no intention to prevent me writing in the Star. Moreover whatever I wrote should appear unaltered and unmutilated by him. Hence the appearance of my letter in the Star.

Whether the quarrel will end for the present depends upon what he writes this week. But at the very best there is but an armistice between us. He has wronged me too deeply, and I have told him too many unpalatable truths, both publicly and privately, $[\ldots]$ for us ever again to be very 'good friends'. Besides our principles - so widely differing - must provoke new and serious collisions. In this affair I am the victor. [...]

As soon as I see the means of making an independent start I

${ }^{1} \mathrm{~L}$ IV $\mathrm{x}$ go. Following the revolutions of $\mathrm{I} 848$ and the imposition in England of a new Aliens Act that gave the Government almost a free hand in deporting cmigrés, the formal connection that the continental revolutionaries had with the Fraternal Democrats came to an end in May 1848 . Henceforth the Fraternal Democrats were the radical wing of domestic Chartism only. For all that the informal contact that Harney and his friends had with the emigrés seemed to be none the less. It was because he involved himself with all who came to England, regardless of their political position, that Marx took issue with him. His dispute with O'Connor had another cause besides that of internationalism. It concerned relations with middle class Radicals. Harney was intensely suspicious of the "Manchester School" - in fact he wrote them off. The great debate about the class character of political organisation is continued throughout the whole history of Chartism and is never resolved.

In the spring of I 849 the Radicals led by Sir Joshua Walmsley, Joseph Hume and Lord Dudley Stuart formed yet another reform association "The Metropolitan Financial and Parliamentary Reform Association" and the question of Chartist co-operation with this body split the movement right down the middle. O'Connor allied himself publicly with the new organisation and appeared on its platforms. This was at a time when many of the established Chartist leaders were in prison following the demonstrations of 1848 . O'Connor regained control of the Chartist National Executive. As a means of building the opposition Harney and the Fraternal Democrats announced a banquet to celebrate the first anniversary of the 1848 French Revolution. To this were invited all likely allies including the Owenites, G. J. Holyoake, Walter Cooper, Bronterre O'Brien and the Scots publisher Robert Buchanan. As from this occasion it was a fight to the finish. 
mean to 'take the field'. Of course you understand this to be a private letter." 1

The next letter is dated May ist I849:

“The question between me and O'C. remains where it was when I last wrote. I think I have not seen him since. You may have noticed in the Star unmistakeable indications of his ill-feeling although not expressed in plain terms. But I heed him not, having good reason to know his power is fast crumbling to dust; and that on the other hand, my friends are daily increasing..."

Later in the same letter he writes about his proposed paper:

"I have no doubt of the success of a weekly unstamped which could be easily produced; but in that case be would consider he had a fair excuse for giving me notice to quit. There is, however, an opening for a monthly publication. The Labourer (sixpenny monthly) ceased with the year 1 848. In February i 849 Fleming and McGowan started the Commonwealth (also 6d) but it too after a three month sickly existence has ceased to appear. Having consulted my friends I have determined to bring out a monthly publication, price 3 pence, to commence on ist of June. The title will be

The

Democratic Review

of

British and Foreign

Politics, History and Literature

etc etc etc,

I hope to make this successful and keep my employment at the Star office also - at least for a time. If the monthly speculation should prove successful it will lay the foundation of success in greater undertakings.

Something from your pen for each month's number I consider most necessary."

He added a postscript dated May 2 nd:

"Brandenburgh's second coupd'état promises to hasten the day when you will be citizens of the German Red Republic or slaves of the Russians. You have my anxious thoughts for your safety and victory. Perhaps these new events may prevent you[r] writing but I know you will do so if possible. Louis Blanc and Caussidière dined with me last evening. They both promise me assistance for the Democratic Review."2

'L IV r 52. In this same letter Harney records that he has just had "news from America of the sad death of one of my brothers by drowning".

${ }^{2} \mathrm{~L}$ IV 153. 
In the summer of 1849 the Hungarians, defending themselves against Russian and Austrian troops, were the heroes of British public opinion. All over the country well-attended meetings supported them. Often Mayors presided. People of every class turned out, but whereas parliamentary radicals like Cobden urged only private action to require the Russians to make peace, the Fraternal Democrats demanded British military intervention. At meeting after meeting the pro-war party carried the day. The Times commented sarcastically, "Lord Dudley Stuart and Mr Julian Harney, $\mathrm{Mr}$ Monckton Milnes and Mr Hetherington, in conclave assembled, have had the glory of adding another point to the People's Charter... 'fraternity with all democracies'." The movement in defence of the Hungarian Revolution was soon deeply divided into two camps but events in Hungary itself forestalled any further developments in Britain. By August the revolution was defeated and Kossuth in flight.

Harney, who had stumped the country with phenomenal success emerged with a greatly enhanced reputation and it was in the next few weeks that he determined to bring matters to a head in the conflict over the Chartist leadership. He had come to the conclusion, as Schoyen puts it, that "Chartism could be revived as a mass movement in the future only if it adopted a socialist as well as a democratic programme". ${ }^{2}$ In the winter of $1849 / 50$ the factional struggle within Chartism rose to a climax. A battle of words was fought out in the Northern Star between the O'Connorite Thomas Clark and Harney. Conference followed conference. Both sides lobbied the movement. Then came the moment Harney had long anticipated. He was finally refused space in the Northern Star in May 1850 and resigned the editorship. This, as he saw it, was not a defeat. It was part of the tactics of victory for at almost the same time the Fraternal Democrats swept the board in the election of the new National Executive. O'Connor and the O'Connorites were out; some of them had already set up a National Charter League of their own to work with the Parliamentary Reformers. The new leadership of the National Charter Association forthwith adopted a socialist "declaration of social rights" making their Association the first social-democratic party in Great Britain.

\footnotetext{
1 Democratic Review, August 1849, p. 83 . The Times, 26th July I 849 . The papers owned and edited by Harney in this period were as follows:

Democratic Review: June I 849 - May I 8 so. Monthly.

Red Republican: June - December 1850 . Weekly.

Friend of the People: Ist series December 1850 - July 185I; 2nd series February - April I 8 52. Weekly.

Vanguard: January - March I853. Weekly.

'Schoyen, op. cit., p. 193.
} 
Having left the weekly Northern Star Harney now promptly wound up the monthly Democratic Review and produced a new weekly, The Red Republican, to serve the purposes of the movement in its new character. The first issue appeared in June.

Ernest Jones, imprisoned on charges arising out of the demonstrations of 1848 , came out of prison in July i 850 . He had joined the Chartists late in the day - in I 846 - and had been completely in accord with O'Connor with whom he had co-edited the Labourer, a journal devoted primarily to the land scheme which O'Connor had said: "has no more to do with Socialism than it has with the comet". ' But like so many other prisoners of ' 48 Ernest Jones had changed his mind whilst "inside". He emerged a socialist. "When he rode through densely packed streets of cheering Chartists in Halifax beside Harney, the only other leader invited by the Lancashire and Yorkshire Chartist delegates, it must have seemed to both that a new dawn of Chartism had broken. Delegates from twelve localities, and a crowd estimated by the Northern Star at 30,000 listened on the next day to a series of speeches which reiterated the message of the Halifax address to Jones: 'The war of classes, sir, is now no longer a mere war of politics, but a war between capital and labour.' The change between 1848 and 1850 , Harney declared, was symbolised by the change in the Chartist flag colour; when Jones went to prison it had been green - now it was red. The irony of the moment was mercifully hidden from the jubilant crowd; Jones's release meant the beginning of the last deadly struggle within the Chartist movement."2

But one must not anticipate. The struggle against O'Connor was not yet over despite the old leader's defeat in the elections for the National Executive. The last six months of 1850 saw some fierce infighting in the National Charter Association and in this Harney and Jones were closely allied against O'Connor. Harney saw the Association as the nucleus of a new party rather than as the new party itself. In August, therefore, he called a "Democratic Conference" with delegates from the Fraternal Democrats, the Owenite socialists, the Christian Socialists, the Social Reform League, O'Brien's “National Reform League", the Metropolitan Trades Council and individual reformers. It was not very successful. There were too many little power-groups apprehensive that they might lose their identity in an organisation dominated by the National Charter Association. O'Con-

1 Northern Star, Isth April 1843.

${ }^{2}$ Schoyen, op. cit., p. 198. It was in the following month, September 1850 , that the Barclay and Perkins draymen gave General Haynau good cause to know what they thought of him. 
nor was bitterly hostile to the whole project and actively organising opposition. Harney wrote to Marx on October 26th 1850 :

"The movement party is in such a state of chaos at present that to write thereon and venture an opinion as to what will be the state of the party two months hence would need the qualifications of a prophet - certainly not possessed by

\section{Yours ever fraternally \\ And devotedly, \\ G. Julian Harney."'}

O'Connor and the anti-socialist Manchester Chartist Council called a Chartist Conference in Manchester for January I $85 \mathrm{I}$. Before it met it was repudiated by the majority of active Chartists and only four localities sent delegates. This is the background to Harney's next letter to Engels written on December 4 th 1850 :

"The devil to pay on Wednesday night. I carried resolution to send E. Jones to the West Riding Delegate Meeting at Halifax (tomorrow). Carried resolution 6 to I - O'Connor against - repudiating and denouncing the Manchester Conference. Carried resolution denouncing the denunciation of E. Jones. Opposed by $\mathrm{O}^{\prime} \mathrm{C}$ - and Reynolds and (because 'too strong') by Holyoake. Subsequently the three signed a modified expression of confidence in Jones.

Jones will be in Manchester this evening - at the Waterloo, or Wellington, in some street back of the Mosely Arms (the Mosely Arms is opposite the Infirmary). Jones could not give me a more accurate account of the place.

If you cannot see him this eve go to the Institute tomorrow evening. He goes to Halifax in the morning and returns in the evening to face his foes. Be there if possible and if you can give him any help do so. It is likely the gang will try violence - if they dare. $\mathrm{O}^{\prime} \mathrm{C}$ told Jones he would be flung from the platform and his life would be in danger!!!

I expect the Manchester gang will furiously denounce me. I will write again in a few days.

PS Mantle's address is 39 Henry Street, Oldham Road. He will most likely be with Jones this evening."2

In November I 850 Harney published the first English translation of the Communist Manifesto in The Red Republican. It opens: "A frightful hobgoblin stalks throughout Europe..." About the same time, and in the light of the previous disappointment with the

1 D IV 207.

${ }^{2} \mathrm{~L} \mathrm{IV} \mathrm{I56.} \mathrm{The} \mathrm{meeting} \mathrm{"on} \mathrm{Wednesday} \mathrm{night"} \mathrm{was} \mathrm{presumably} \mathrm{that} \mathrm{of} \mathrm{the} \mathrm{London}$ Association. 
conference on the subject of the new party, he had come to recognise that the name of his paper lost friends for its cause. He decided to rechristen it The Friend of the People and this decision took effect in December 1850 . He wrote to Engels again on December 9th to tell him that he had been very ill with a throat infection and to say that he did not feel "quite assured against a relapse". He went on:

"Holyoake and other friends kindly brought out a preliminary number of the Friend of the People and furnished the articles for No. I. I was not able to do anything for either Nos. I hope to be able to do a little for No. 2.

If you come to London at Christmas be sure to see us. The pipe of peace shall be forthcoming, and the fire-water shall not be wanting."1

Engels then wrote to Harney on the subject of the Manchester Conference and on December I 6th Harney replied:

"Herewith I forward the numbers of the Red Republican and the Friend of the People.

The address of Miss Macfarlane is: Helen Macfarlane, Bridgend, Burnley. Don't forget the 'Helen'.

I am not surprised to find you expressing your disgust at Manchester. It is a damned dirty den of muck-worms. I would rather be hanged in London than die a natural death in Manchester. The Chartists there are the worst lot in the country. A degraded crew of slaves and sycophants. Think of Leach sinking into the contemptible character of lacquey to O'Connor. Most of 'th'owd chap's' followers are poor ignorant blockheads, but Leach knows better. There is no man who more thoroughly understands the real character of the great $\mathrm{O}$. It is disgusting.

If you see the Star you will know how inveterate the gang are against Ernest. In the meantime Feargus slavers [over] him in public and denounces and plots against him in private. This Ernest knows and seems quite resolved to fight out the battle. Most likely there will be some notice of these matters in the next $F r[i e n d]$ of the P[eople $]$.

How glad I am you are walking into those middle class humbugs, particularly that you frightened that boasting fool the bagman."2 On January 25th i85 I Harney wrote the last letter to Engels before the first major break in the surviving correspondence:

1 L IV I57.

${ }^{2}$ L IV I 58. The reference to Helen Macfarlane (who did the English translation of the Communist Manifesto published in the four November issues of the Red Republican) provides added evidence to confirm Schoyen's conjecture that "Howard Morton" (a regular contributor to the Red Republican) and Helen Macfarlane were one and the same person. 
"Could you see Mantle and other friends, and arrange for me to get information concerning the proceedings of the "Manchester Conference'? I should like to know the list of 'delegates'(?), the purport of their principal resolutions, the sayings of those 'chosen' renegades Clark and McGrath and the course taken by O'Connor.

Tomorrow morning there is a meeting at my home to decide upon the projected paper.

I will write again next week."

The next letter is dated Jan. I 4th I 858 . It would be good to be able to believe that the seven years breach was simply due to the fact of the correspondence having been lost. Unfortunately there is a great deal of evidence to show that, politically at least, the relationship was suspended during those years. No sooner had O'Connor's Manchester Conference failed than a rift began to appear between Harney and Jones or more particularly between Harney and Marx and therefore with Jones. Marx had long been critical of what he regarded as Harney's indiscriminate predilection for revolutionary emigrés regardless of their political complexion. There were at least three French factions in London, Louis Blanc's utopian socialists, Ledru Rollin's Société la Révolution and a Blanquist minority led by Felix Pyat and Bartlelemy. Harney mixed with all of them. The situation had been further complicated since the summer of 1850 by the formation of a middle class non-socialist republican "Central European Committee" led by Mazzini, Rollin, Ruge and a Pole, Darasq. Emigré politics became increasingly unreal as 1848 receded. Marx and Engels solved the problem for themselves by cutting their own links with all emigré groups.

On the third anniversary of the revolutions of 1848 both main French factions in London decided to hold banquets. They were to take place on the same evening, February 24th, and in opposition to one another. Harney resolved to go to each of them but to Rollin's only cursorily. At Blanc's he and a large number of his friends would make it clear where their main sympathy lay. Marx expressed himself very forcibly: "He has by no means been content to take part at the meeting of these people. No. He has made their banquet of the 24 th February, which without him would have been a complete failure, into a London event. Already a thousand tickets have been sold. [...] Harney has sold the largest part of the tickets, as Jones told me the 
day before yesterday. O'Connor, Reynolds and hundreds of Chartists are taking part. Harney has drummed them together. He is on his way all day carrying out the orders of Louis Blanc, as Jones told me also.[...] Jones declared to me that in view of my explanations he would probably $[. .$.$] not be present at the banquet. What makes his$ decision uncertain is very rational. If he doesn't come he loses his popularity as, thanks to Dear [Harney] this banquet has become a Chartist matter. [...] Jones disapproved of Dear's behaviour.[...] He attempted to excuse it by saying that if the Chartists did not take part in either of the two banquets, they would be accused of political apathy or of antipathy against the foreign revolutionaries. I answered him, then Harney should have held a Chartist meeting in celebration of the lousy 24th of February instead of making himself into a pedestal for a dwarf and half a dozen camels." 1

This difference became a turning point in the history of Chartism. Schoyen's own conclusion is unambiguous - that Marx and Engels "wanted an obedient conformity to their position on all matters. Anything less was treasonable."2 This severe judgment seems to be close to the truth at least as regards the relationships of the 'fifties. It was certainly not true of the later years as the subsequent correspondence will show. But then, of course, Harney was no longer playing any leading part in politics. The division at the top of the movement took time to work its way down. At the beginning of the year (1 $85 \mathrm{I})$ Harney's star was in the ascendant domestically and internationally. The Chartist Conference in March adopted a twelve point programme that incorporated the six points of the Charter and the case for socialism. But in 185 , the year of the Great Exhibition in England, the country was prospering and the European political revolution had gone down to incontestable defeat. In May i 85 I Harney wrote: "It has been asserted that Chartism exhibits the spectacle of a head without a body. This is in some measure true. But where the fault? Only from below can the movement be reborn."3 Earlier, in January, he had pointed out that political advance was cyclical but that in times of political reaction significant things could and did take place socially and industrially. He was, accordingly and in the present instance, strongly in favour of an alliance with new people among co-operators and trade unionists.

Marx had no more sympathy with this than he had with Harney's allegedly promiscuous internationalism. And again Jones followed

${ }^{1}$ Marx to Engels, February 23rd I 85 I ; quoted by Schoyen, op. cit., p. 2 I 5.

2 Schoyen, op. cit., p. 2 I6.

${ }^{3}$ Friend of the People, May 3 rd 185 I. 
Marx. Marx wrote to Engels on May sth I85 I: "Yesterday Jones gave a really splendid lecture directed against the co-operative movement, and making a frontal attack on his own public." At this same time Jones started his own paper Notes to the People in opposition to Harney and on July 3 I st Marx wrote to Engels about it: "By the way, it would be good if you would write and sign an article for Jones. He is making good progress with his paper, he is learning. He is not like Harney. Consequently the Notes to the People is gaining ground while The Friend of the People is collapsing."' Jones's uninhibited, uncomplicated, sectarian enthusiasm carried conviction in what was left of the fast dwindling ranks of Chartism. Harney's new thinking was too far ahead of its time. The support he hoped for was not forthcoming and he closed his paper down in July i $85 \mathrm{I}$.

In the following months O'Connor mental health gave way. The Northern Star changed hands and declared "Away with the name of Chartist, it is offensive to both sight and taste." Harney came to the conclusion that the National Charter Association, as the organisation of the movement, was dead and in December $185 \mathrm{I}$ he refused to stand for the new Executive. But he distinguished between the movement and the organisation and he had certainly not given up. $\mathrm{He}$ resolved to restart the Friend of the People on a new and broader basis as a popular radical paper. This worried Jones and on January 6th 1892 he wrote to Engels:

"Yesterday evening I was at Marx's. Probably he will write to you about our conversation. I have explained to him the relationships of the 'Notes' Harney and myself. Harney is editing a new paper (Friend of the People) at tbree-balfpence. [...] It is directed against me. He has quit his connection with the newspaper in order to be able to do this. ${ }^{3}$ Three weeks ago I made him an offer that he should join me in producing the 'Notes' I did this only out of friendship for him for the 'Notes' run better every week and keep out of debt. He did not accept for, as he said, 'You have attacked the co-oper-

${ }^{1}$ John Saville brought together a collection of Chartist material centred on Jones in his Ernest Jones, Chartist (London I952). This is from that collection. More explicitly he quotes Jones in his own Notes to the People, Vol. II, p. 976 as follows: "We therefore say, at this the critical time: All trades unions are lamentable fallacies, whether they embrace 1,000 or $1,000,000 \ldots$ All co-operative efforts are waste, misdirections of time, means and energy, under our present governmental system." (March I 852, p. I95 and see also p. 234.) Marx himself, in his Wage, Labour and Capital, written and rewritten as a lecture in the 'forties, did not mention trade unions.

${ }^{2}$ Quoted by Saville, op. cit., p. 235.

${ }^{3}$ This reference is not clear to me. The original German text is unambiguous. Presumably Harney worked for some paper not his own in the second half of $185 \mathrm{I}$ after the demise of the first series of the Friend of the People. 
ators and trade unions. I have not done so and so I have good relations with them. I think as you over co-operation and trade unions but I tbink it is not politic to express my opinions.' For that reason I cannot have anything to do with the Notes.

At the same time be said that he had already printed his circular, of which I enclose a copy. I tell you it is directed against me, more, it is directed against us. Schapper, Willich, Louis Blanc, [?], Holyoake, Fleming, Reynolds, all, will back Harney to defeat us. The Star, Reynolds and the Leader in England, the Sentinel in Scotland, will assist him. [...]

From the circular you know that other people's things will predominate in Harney's paper. The public want things like this. $I$ need it also - otherwise I shall end in ruination.

Nobody can help me but you. Will you write a weekly letter for me as 'Our Foreign Correspondent' or 'Letter of an Exile' or some other non de guerre which can balance Harney's letters 'L'Ami du Peuple'.

You know the "Notes" - so a page at least or two at most minimum et maximum. Do so for fraternity's sake.

I hear that you are disappointed because I didn't visit you when I was in Manchester. I hadn't time to go to bed - or hardly so.

Write! Write! Write! Write!"1

Harney's new paper appeared in February i 8 52. In April he discontinued it in favour of the Star which he had just then acquired and renamed the Star of Freedom. He campaigned for a "new birth" of the old cause and opposed "any attempt to galvanise the dry bones of a worn out past". He advocated and practised association with trade unionists, co-operators and Radicals who stood for the Six Points. His new principal ally was William Newton the organiser of the powerful Amalgamated Society of Engineers, the union that was to be the "New Model" for all unions until the Dock Strike of i 889 .

Ernest Jones called a Chartist Conference at Manchester. It elected a new rival Executive of three i.e. himself, Gammage and Finlen. The conclusions of the conference were widely repudiated. Of the West Riding localities, for example, I 3 out of I9 refused to accept them.

In the General Election of I 8 \& 2 Harney at the very last moment accepted an invitation from the non-electors of Bradford to stand in their constituency. He did no work for the election and arrived too

\footnotetext{
${ }^{1}$ MF II 73. The whole of this letter is in German. Jones was born in Berlin and brought up in Germany until the age of 19 . His father was equerry to Enst, Duke of Cumberland, who became King of Hanover when in 1837 the Salic Law barred Queen Victoria from the succession. Jones was christened Emest after the Duke who was his god-father.
} 
late to make even a single speech. He was humiliatingly defeated at the show of hands. Five years earlier, again at the show of hands, he had won his great victory over Palmerston. The contrast was as total and as unhappy as it could be. Jones won on the show of hands at Halifax.

Newton then proposed diluting the political programme envisaged for the new party urging that it centre on one point only - manhood suffrage. He further proposed that the name of the party be the National Party. Under conditions of decline he urged a bid for increased middle class support but the discussion showed that new support was not forthcoming even on these terms. Newton's own interest in the project declined. Harney's also - he clearly regarded this new development not as "new birth" but as the end of the road. His militant friends had dropped out of the political movement, emigrated, or like Marx and Engels, were with Jones. He accepted defeat at the hands of circumstance and sectarianism and at a meeting in Finsbury said he would no longer take a leading part in the movement. He was as good as his word. The last issue of the Star of Freedom appeared in November I 8 52. Jones, with his Notes to the People newly transformed into the Peoples Paper, was left in possession of the field. In the first three months of 1853 Harney, still aged only 36 , undertook his last independent venture, the publication of a weekly paper $V$ anguard. In February his first wife, Mary, died and in March he discontinued the paper. In the last issue he indicated that he saw the hope of the future not in English politics but in the struggle for democracy on the continent. The last public notice of the Fraternal Democrats dates from July 1853 .

But what of Jones? His importance is that of founder of modern left-wing sectarianism, certainly in England and perhaps in Europe. There had been plenty of religious sectarians and any number of political utopians before Jones. But modern left-wing sectarianism is a condition possible only when a working class and a theory of its ultimate historical significance (whether that theory be right or wrong) had appeared. By virtue of the eighteenth century industrial revolution in England it was there that a working class as such first appeared and it was there, in the Chartist movement, that it first became politically conscious of itself. Marx, Engels, Harney and Jones therefore met in circumstances that were quite without precedent. Their achievement and their failures became prototypes for the epoch in which we are still living. Jones was the first man (at least in England) to accept Marx's theory of the dictatorship of the proletariat as a working basis for an organisation. Just as Harney talked of 
a "new birth" so Marx and Engels talked of a "new basis" for the future of the movement: "Jones is quite on the right lines for this, and we may well say that he would never have got on the right road without our teaching, for he would never have discovered how the only basis on which the Chartist Party can be reconstituted, namely, the instinctive hatred of the workers for the industrial bourgeoisie can not only be preserved and enlarged, developed and based on enlightening propaganda, whilst on the other hand one must still be progressive in opposing reactionary desires and prejudices among the workers."1

Harney on the other hand, although his opposition to the system was equally uncompromising and his class consciousness equally acute, was feeling his way forward from a different political valuesystem. He used a different political language. He insisted upon talking and writing about ends, about what was to replace the system that the Chartists wanted to sweep away: "justice to all... the abolition of classes... an order of things in which all shall labour and all enjoy...the welfare of the whole community..."2 The difference is fundamental and had to lead to a parting of the ways. Harney did not subscribe to the dictatorship of the proletariat. The centre of his philosophy of politics turned upon the meaning of freedom. When in later years Harney and Marx became good friends again and Harney and Engels the closest of friends this fundamental difference over the meaning of class and of ends and means was never resolved. It never divided them again as it had done in the 'fifties because they were never together again in organised action. As late as 1894 Harney and Engels were completely at variance over the assassination of President Carnot and Harney wrote: "I have written reluctantly and more than I intended for I hate to even seem to differ from you. Perhaps I am too 'dull' to understand and appreciate the ethics of modern revolutionaries.[...] You and I see through different 'glasses' I would rather see you through a glass of good Rhine wine, or even 'Scotch' or 'Irish'!"3

In the hands of Ernest Jones, Chartism died. In March i 854 he called a "Labour Parliament" in Manchester. Its declared purpose was to set up "The Mass Movement". There were to be five departments to direct The Mass Movement: "The Secretary of Agriculture is to superintend the purchase and management of landed estates and all connected with the same. The Secretary of Manufacture is to exercise

${ }^{1}$ Engels to Marx, 18th March I852; quoted by Saville, op. cit., p. 236.

${ }^{2}$ Red Republican, October I 2 th 1850.

${ }^{3}$ L IV 257 and L IV 258. 
like function, in reference to all the factories, workshops etc established by the Movement etc..." It is unnecessary to continue the quotation. Yet it was to the assembly convened explicitly to consider this document that Marx wrote: "I regret deeply to be unable, for the moment at least, to leave London, and thus to be prevented from expressing verbally my feelings of pride and gratitude on receiving the invitation to sit as Honorary Delegate at the Labour Parliament. The mere assembling of such a Parliament marks a new epoch in the history of the world. The news of this great fact will arouse the hopes of the working classes throughout Europe and America."2 Nothing more, of course, was heard of the "Parliament". And Marx, naturally and before long, was facing the facts and writing very differently about Jones and his works: "In spite of the force, endurance and energy, which one is bound to admit he possesses, Jones spoils everything by his urge for publicity, his tactless fumbling after pretexts for agitation and restless desire to move faster than the times. When he can't make a real agitation, he seeks the appearance of agitation, improvises movements on top of movements (which of course leave everything where it was) and periodically deceives himself into a false exaltation. I've warned him, but in vain."3

That was in 1855 . The following year Jones proposed a "Call to Action" giving all effective power to himself and Finlen: "If we say 'organise' you must organise - 'assemble', you must assemble ..." No one was listening any more. ${ }^{4}$ On May 5th I 856 G. J. Holyoake wrote to Jones: "On Wednesday evening the 7 th inst at 7.0 o'clock a meeting is called at Anderton's Hotel, of all classes of Reformers, to proceed with an agitation for the suffrage. Will you do the conveners the favour of being present?"5 Jones declined to attend in a letter the final paragraph of which reads as follows: "The Chartist body is the only powerful political organisation in existence and one, which experience must have taught you, no separatist movement can successfully oppose, from whatever class it may emanate. The Chartist organisation is now rapidly progressing towards national ascendancy, and the hour of its final victory is, you may rest assured, very near at hand. Under these circumstances I cannot see any utility in my attending your meeting." 6 About this time Jones, surrounded by the wreck-

1 Saville gives this document in full. It is a classic of its kind; op. cit., pp. 264-272.

2 Dated March 9th 1854 , published in the People's Paper, March 18 th 1854 ; Marx and

Engels, On Britain (Moscow 1953); also in Saville, op. cit., pp. 274-275.

${ }^{3}$ Marx to Engels, February 13 th 1855 ; quoted by Saville, op. cit., p. 239.

- Saville, op. cit., p. 6I; People's Paper, January 26 th 1856.

' IISG, Amsterdam, uncatalogued.

- IISG, Amsterdam, uncatalogued. 
age of his former hopes, was obliged to admit (although not formally so) the correctness of Harney's "new birth" conclusions. He sought the alliance of co-operators, trade unionists and more particularly some of the middle class Radicals. It was over this that Marx took the decision he communicated to Weydemeyer on February ist I859: "I have broken with Ernest Jones."1

Even the indomitable Jones then saw that his efforts, in the forms they had assumed to date, were at an end. On April 3 rd i 860 he wrote to a friend: "The papers are dead. But I remain unchanged and I shall never turn lecturer for money. I adhere to the Charter and shall work for it anew." $2 \mathrm{He}$ accepted the ending of his particular Chartist relationship with Marx but not the finality of the breach. He wrote to Marx:

"I have read a series of infamous articles against you in the National Zeitung and am utterly astonished at the falsehood and malignity of the writer. I really feel it a duty that every one who is acquainted with you, should, however unnecessary such a testimony must be, pay a tribute to the worth, honour and disinterestedness of your character. It becomes doubly incumbent in me to do so, when I recollect how many articles you contributed to my little magazine the 'Notes to the People' and subsequently to the 'Peoples Paper' for a series of years, utterly gratuitously, articles which were of such high value to the people's cause, and of such great benefit to the paper." 3

At some later date Marx relented. He and Jones were actively associ-

\footnotetext{
${ }^{1}$ Saville, op. cit., p. 243. It was to the middle class Radicals that Marx took exception. He, like Jones, had come or was coming to recognise that Harney had been right in his empirical acceptance of trade unionism and co-operation. But to Matx empiricism was not enough. At the critical time, I $850-1852$, he had yet to work out definitively his theory of value, surplus value and the rate of exploitation. This he did some five years later in his Critique of Political Economy written in 1857 . He then had an entirely rational basis for his re-assessment and acceptance of trade unions. Thus he could write in the resolution he drafted for the Congress of the International Working Men's Association, Geneva, I 866: "If the trade unions... are absolutely indispensable for the daily or guerilla warfare between Labour and Capital, they are... all the more important as organised bodics for the abolition of wage-labour and of the capitalist domination." This would seem to explain the otherwise hopelessly confused and unintelligible situation between Marx, Engels, Jones and Harney in the 'ffifties.

${ }^{2}$ Saville, op. cit., p. 73 ; letter in the Howell Collection.

${ }^{3}$ MF II $4 \mathrm{I}$; February 1860 . There is a considerable number of letters from Jones to Marx in the archives. They are catalogued MF II 27 to MF II 71 . Most of them are short notes. Many are written in German. A number are so badly written (Jones's handwriting is as temperamental as its author apparently was) or have been so ill used by some physical circumstance as to render them partly, sometimes wholly, illegible.
} 
ated again at the time of the First International. ${ }^{1}$ Jones died in January I 869 aged 50.

But to return to Harney. He left London late in 1853 to go to Newcastle-on-Tyne to join his good friend the young radical industrialist Joseph Cowen Jr who was as convinced as he was of the critical importance of continental revolution for the next stage in the struggle. They saw revolutionary possibilities in the Crimean War. Harney helped to build the influence of the Newcastle Foreign Affairs Committee and to edit the new monthly, Northern Tribune, the first issue of which appeared on January ist I854. In 1855 Napoleon III paid a state visit to England and Felix Pyat of the Commune Revolutionnaire wrote a threatening article about the "bloody usurper and assassin of December 2nd". This was published in London and nothing happened. It was then republished by a French emigré group living in Jersey. Victor Hugo was among their number. They were all promptly deported from the island, some to Guernsey and others to London. Harney went down to the Channel Islands on behalf of the Newcastle Committee to investigate the situation and do what he could to help. Whilst in Jersey he fell sick. Taking to the place he convalesced at leisure. It so happened that at that time the position of editor of the twice weekly paper the Jersey Independent fell vacant and he was offered the job. He took it and kept it until his unambiguous support of the North in the American Civil War led to his departure in 1862 . In those years he married again and he and his wife, Marie, adopted a son. ${ }^{2}$

In 1857 Engels visited Jersey, met Harney and wrote to Marx: "I went drinking with him and had him tell me about the local constitution, etc.; there was no talk of bygone days. For the moment he sees damn'd glad to have retired from high politics to his little kingdom of the blind. As a one-eyed man he is king of the opposition." 3 There are seven surviving letters from Harney to Engels written from Jersey early in 18,8 . They concern the death of Schramm the German revolutionary. He died in Jersey on January i 5 th 1858 and Harney's

\footnotetext{
1 Jones to Marx on February I 8th I 865 : "I forgot to ask you in my last letter to enrol me as a member of the International Association, and if you send me a dozen cards I dare say I could get a dozen members. If not I would return the cards." (MF II 49) There are a number of letters dealing with the 1865 to 1868 agitation in England (and with special reference to Manchester) but they and their context are beyond present terms of reference. ${ }^{2}$ Her maiden name was almost certainly Le Sueur. On August 3 oth 1885 Harney sent Engels a list of names and addresses of people in Jersey. In it he listed Mrs Harney's brother, Francis Le Sueur of "The Impot" Quayside, Jersey.

${ }^{3}$ October 6th 1857; quoted by Schoyen, op. cit., p. $24^{8}$.
} 
letters are about his funeral, his estate and the particulars that he wanted for the obituary he then published in the Independent. ${ }^{1}$

\section{III}

There is then a gap in the surviving correspondence with Engels until 1876 . The Harneys emigrated to America in 1863 and in 1864 Julian went to work in the office of The Secretary, Commonwealth of Massachusetts, Boston. He wrote to Marx in I 87I about a copy of an official report he was trying to get for him. He commented, in passing, on the poor situation in Europe, "Garibaldi lost heart and hope and gone back to his island; and even French Generals counselling peace and submission; there can be no renewal of the struggle."2

He wrote to Engels on April i ith i 876:

"I was truly sorry to learn by that line inserted in the Examiner of the death of Pfaender [...] And Freiligrath is gone [...] And Blanqui is dead - in his prison cell - liberated in spite of McMahon and Thiers and all the knaves and cut-throats. I suppose Blanqui was a good deal of a mystery. It is certain he was a martyr. Has he left any 'literary remains' and any disciple willing and able to vindicate the character and give a clear exposition of the aims of his master?

And what is friend Marx doing? He is as quiet, though doubtless not as still as the grave. The man who but yesterday (as Finlen would have said) 'made the bloody tyrants tremble!' How is it we fail to get in English any full, clear, methodical representation of his views, doctrines, philosophy or what you will?

A year ago - I think it was in March '7s, there appeared in the 'Fortnightly Review' an article by one John Macdonell on 'Karl Marx and German Socialism'. If I remember right it seemed to be written in a fair spirit, but was nevertheless very unsatisfactory. I had some expectation of seeing in the 'Review' an article in reply from the pen of Marx or yourself. But nothing appeared. As usual I neglected, but will name now what I thought of saying then, that (with others - alone it would have been useless) I would have contributed a small sum - say a Pound, toward cost of printing [a] pamphlet or book exhibiting the system or views or ideas of friend Marx. Now I will do so on word from you. If a pamphlet I would have asked a copy or two in return - if a book I would have been content to buy the book with the rest of the public.

Your brief sketch of European movements as they then appeared

I L IV 160 to L IV I66.

${ }^{2}$ February $17^{\text {th }}$ I $87 x$, D IV 209. 
(June I 875) I found very interesting. Should be glad to hear again on the same theme. Hell to pay in Turkey - that (the Ottoman) state ruined by English and other bond-holders. Cowardly and contemptible is the attitude of the English government, and imbecile is the common idea of allowing Turkey to go to the dogs. I have never changed my view of the Crimean War - just and necessary, but villainously and treacherously mismanaged. Never never should the Muscovites encamp on the Bosphorus had I my way. Rather all Europe in flames.

Remembrance to friend Marx."1

It was at this time that Gladstone wrote his famous pamphlet against the Turks, The Bulgarian Horrors and the Question of the East. Harney replied with his own pamphlet The Anti-Turkish Crusade and sent one to Engels:

"Instead of Peter Taylor, Gortschakoff might be the proprietor of the Examiner. If he is not then he gets his work done cheap.

Is the general madness pervading England? Is Bedlam let loose? I do not suppose you follow Gladstone; but I anticipate that for reasons of your own you do not share my views; nevertheless I enclose with 'Documents' my pamphlet.

Of course I anticipate 'no sale'. A pamphlet to succeed should be backed by a 'great name' or plenty of money to advertise. I have neither. Yet I did say [...] that should there be any demand any one might reprint without losing time consulting me."2 And then on May 14th I877:

"See in Pall Mall Budget April 27/28 page 16 an abridgment of a speech by a Russian peasant Aleksieyeff, one of the accused in 'the late socialist trial' at St Petersburg. That speech was suppressed in the papers, but was printed at the secret socialist press of St Petersburg!

You probably have said speech. Could you not get it translated into English and printed either in Potter's paper, or better, as a tract?

What is friend Marx doing - I never see mention of his name.

May is. This day's news brings the division on Gladstone's resolution - a majority for the Government of $13 \mathrm{r}$. Good; but scandalous that 223 so called 'Liberals' should have supported Gortschakoff's friend Gladstone. If ever the 'Britishers' come to their senses (if they have any to come to) that man will be as much

${ }^{2}$ L IV I68. 
hated as he is now honoured, and more execrated than he is now applauded."

On January I ith i 878 Harney told Engels that he was without a job. "A change has taken place in my position. I left the State House December 3 Ist, having completed I 3 years." He explained that after the appointment of a senior man "with the abilities of a drill sergeant" the old clerks had been "pushed out to make way for 'soldiers". $\mathrm{He}$ continued:

'Unless some new engagement 'turns up' - very unlikely - to prevent me, I may cross 'the briny' in the spring - life and health permitting. If I reach London I ought to look you up; but I am rather afraid of the Finnegans! I think I had best seek Mrs Marx, she is an old friend of mine, and, for auld lang syne, might protect me with the Pallas like shield of her intervention. Well, we shall see what we shall see."2

Harney received a letter from Engels dated February $7^{\text {th }}$ i $87^{8}$ and replied on March 3 Ist:

"You speak of the degraded state of the Press. Think how this life's successes eternally disappoint us! See that has become of the struggle to 'free the press' for which I went to prison at 17 years of age. Recall Cobbett's Register (no matter its passion and prejudice); recall our unstamped papers, if you ever saw any! And did you ever dream of seeing such a damned crew as our present 'Liberals' and 'Radicals'! O shades of Cartwright, Cobbett, Hunt and Horne Tooke, the leaders and sufferers from I 770 to I 820 - I might add until the fall of Chartism! Think of Gladstone and Lowe and Bright! And, outside, of the shrieking [?] Freeman, that blatant beast Carlyle, that profound Professor Goldwin Smith and Ginx's baby! Well I hope some of these will come to grief, and that first election Ginx's baby will get his starn-post kicked out of Dundee! And then the smaller fry: the Bradlaugh's, Holyoakes, the Trades leaders, $\mathrm{Mr}$ Spartacus [!] Arch, Cremer and the other screamers for peace-atany-price! How does Bradlaugh, I wonder, like the bag and baggage programme when applied in Hyde Park!

Well it looks like War! But why now? [...] Iron-clads cannot march on dry land. Where is there a foothold or an ally?

I have read with pleasure your activities in the Labor Standard. They forcibly remind me of your first contributions to the Northern

${ }^{1}$ L IV I 70.

'L IV 172. The "Finnegans" is a reference to Engels' Irish wife and her Irish family and friends. 
Star when you came from Bradford and I first met you. $O$ for the days that are no more!

Now I am old and with bodily troubles that not only inflict suffering but depression of spirits. I am not at anything new. I am still undecided as to crossing this year. It will be 40 years in I 879 since I sat in the Chartist Convention with Frost, Lovett, O'Connor and the rest."

He then went on to refer to Irish politics and the release, by Gladstone's Government, of O'Donovan Rossa as the result of things written by "the daughter of Mr. Marx. I wish Mr. Marx's daughter better employment in the future." And then:

"If England goes to war and your Finnegan friends think 'Ireland's opportunity' has come, it will only be[a]mercy for you to give them Punch's advice to people about to marry - Don't! If they do instead of don't, the Irish police will suffice; or if that perchance be doubtful England has only to let lo[o]se the Orangemen and the Finnegans will see - what they will see!

You tell me the said Fs will not exactly chaw me up if I call - good. But I must take some precautions against such amenities as a barrel of powder etc.. What would you think of my providing myself with a pair of burn-proof breeches? If you think I have made any mistake in the orthography, you are mistaken. Johnson and Walker and Worcester and Webster and other old fogies, are 'played out'. These are the days of spelling reform and 'spell as you speak' is the order of the day."1

In 1878 an attempt was made on the life of the Kaiser. Harney wrote to Engels on June Ixth:

"and whilst I say that William the Holy ought to have been punished as Charles I and Louis XVI(the latter much less deserving his doom) by due course of law, I feel certain that the socialists as a body have no idea of countenancing anything so absurd as the shooting of that old sinner - who is not the real Emperor of Germany. Nevertheless the socialists will have to suffer for the lunacy of men demented by vanity and with probably certain screws loose."2

He said that he and his wife proposed to embark from New York on July and for Liverpool - on the "Montana"; and that his itinerary was London, Paris, Jersey and London again. On arriving at Liverpool he sent a post-card to Engels:

"Arrived yesterday. Main shaft broken I roo miles from Liverpool.

Found yours at P.O. Sorry to hear of your trouble and more so of

${ }^{1}$ L IV 173. In fact Harney's spelling, like his syntax, is consistently careful and correct,

${ }^{2}$ L IV 174. 
the more serious illness of Mrs. E. Your politico-personal intimation a surprise. Thanks. Will try to write a few lines from Macclesfield - go there this evening." 1

On the way back to America the Harney's left England on September I 4 th. The next letter to Engels, written from Boston, is dated October 8th:

"If I remember correctly I wrote a line to you before I left England, expressing sorrow for your bereavement, which I first learned from my wife. The result I expected but not nearly so soon. You may remember that my first wife died of the same cruel disease; you may also recollect that she lingered many years.

With the best will and intention on my part, it was quite impossible for me to call again. After Paris and the Isle of Jersey, I made a flying visit to Newcastle-on-Tyne and the West of Scotland; from thence by way of Manchester to Liverpool - where Mrs H. met me."

He went on to say that his wife had called on the Marx's in London only to find them away; to learn that Mrs. Marx was at his (Engels') place and that Mrs. Engels had died. Mrs. Harney then went to Engels address "but feeling how inopportune her call would be at such a time she merely rang the bell and left her card in the letter-box". He continued:

"If life is spared and all goes well, hope to be in London early in the New Year, and then have opportunity to make good lack of performance in seeing friends when on my recent high pressure visit.

I write to Mr. Marx by this mail. [...] You were not very well when I saw you. I hope you are better of that trouble in your foot and otherwise in better health."2

About the same time Harney wrote to F. A. Sorge: "In London we saw Dr Marx and Engels. Marx though very grey seemed healthy and strong and youthful intellectually. Engel's wife was in a dying condition and expired before we left England. Engels himself still keeps a good deal of his youthful, almost boyish look. Mrs Marx was in poor health. They were pleased to hear from you and interested in all I could tell them of your welfare." And à propos the international situation: "When American capital gets frightened, it will be more bloodily pityless than European kings were, and at least rival Thiers myrmidons in their St Barthlomews of the supporters of La Commune."3

${ }^{1}$ L IV I 75, July 20 th 1878 .

2 L IV 176.

3 Two letters dated November 8 th and i 8 th 1878 , uncatalogued. 
Harney returned to England in 1879 , not in the New Year as he had hoped, but almost at the end of the year. Back in America again he wrote to Engels in January I 880:

"Parnell has reached New York and is, I believe, to be in Boston on the I 2 th. That will be a good day to keep away from Boston. I must frankly say I cannot get up the slightest sympathy for Ireland's agitators. I do sympathise with the suffering people, just as I feel for those of Silesia and elsewhere. But in Irish patriots I have no belief. When young I was an enthusiastic admirer of Emmett; but I soon saw through the humbug of the great Dan; and from that time have mistrusted all Irish patriots. The few who may have been sincere have preached a fanatical hatred of everything English, and I am not good Christian enough to return love for hatred. The land agitation, if not mere humbug, is of a kind with which I cannot sympathise. It is not for the nationalisation of the land. It may be to take from the few to give to the many, but it is not to give to all - or rather to the whole."

And then, changing the subject for a prophetic moment:

"It does look as if we might live long enough to see Revolution in Russia. Let it come."1

From a letter written by Harney to Marx on August 10 th 1880 it is apparent that the two men had met on some occasion during Harney's last visit to England:

"On your return to town after receipt of this, friend Engels will hand [you] (if it has reached him) a photograph of your humble servant. In giving me yours you requested mine..."2

And to Engels on the same subject:

"With this I forward per Book Post, hoping they will reach you, two copies of a photograph recently taken. When Dr Marx gave me his he requested mine - which I would hardly have had taken at present, only this is the year of my 'grand climacteric (!)' $\left(6_{3}\right)$ concerning which I feel mighty small. Please hand one copy to $M$ (on his return to town), and one of the within inscriptions. Please accept the other as an addition to your own particular 'Chamber of Horrors'. $[\ldots]$

The pamphlet 'Socialisme Utopique and Socialisme Scientifique' reached me some time ago; and by the help of Mrs Harney I read it. Written with all the ability and vigour which you undoubtedly possess, it seemed to me wanting in explicitness towards the 
conclusion. If the State is to disappear, what is to take the place of the state? If Society is to possess all the implements and means of production - society, it seems to me, must have some organisation answering to the present 'State'.

Your letter: - I cannot discuss the Irish question in this note, but I suspect there is not much difference between us. Meddle and muddle sums up the Gladstone policy abroad and at home. I see there is to be a caucus manufactured agitation against the 'Lords'. Whatever the 'Lords' may be, they are not as evil as the 'Manchester School' and the 'Birmingham Canard'. [...]

Regards to le citoyen and la citoyenne Lafargue. Lucky fellow that! See what a charming wife he has! And to feed like Robespierre on oranges all winter and like Rousseau on creams all summer."1 The inscription to the photograph reads:

"For Auld Lang Syne. To Frederick Engels Esq. From George Julian Harney (of England). Born February 17 i 817 . This photograph taken in Boston, U.S. - May 17 I880. 'They made an Exile, not a slave, of me.' Byron."2

Harney next wrote to Engels on March I ith I88 I to say that he had not heard from Engels that the photographs had been received ("perhaps you did not write to punish me for my egotism") and to add that he was considering coming back to England the following summer. ${ }^{3}$ Engels wrote back immediately and Harney replied by return of post on May 2oth:

"Yours of 3 oth March, with photograph, came all right. The photograph an excellent likeness - though the look a little too ferocious or extra-revolutionary. The expression seems to be that of impatiently waiting for some one to have done with his say, that you may at once demolish and catawumpously [sic] chaw him up! Glad $I$ was not the destined victim. [...]

It does seem that 'the great Liberal party' is destined to go to pieces, and an extreme Radical party may be formed. But I have not much faith or hope. The working class leaders are saturated with the Manchester and Birmingham doctrines, and only eager to get into Parliament under middle-class patronage. Even the great Bradlaugh, the martyr of compromise, has become the very humble servitor of Gladstone, Bright and Chamberlain.

Nicholas and Louis Napoleon I would have liked to have seen brought to trial and executed. But though I could not applaud

${ }^{1}$ L IV I 83, August Ioth 1880.

Also L IV i 83 .

${ }^{3}$ L IV I 84. 
Most's line of action, there was something surprisingly outrageous in his arrest and its accompaniments by the 'Liberal' Government of Gladstone, Harcourt and Co. [...]

I am sorry Beaconfield is gone. [...] His career might have been more beneficial; it certainly was wonderful. The fact that he was so hated by Manchester and Birmingham makes for him a sufficient claim on my sympathies. [...]

Quite unsettled yet whether I cross this year. Probably not."1 And then a moving letter on a most moving occasion:

"My dear Engels,

March 17 th 1883

The Boston Herald last evening contained the following: 'Paris, March 16, Karl Marx founder of the I.W.M.A. died yesterday at Argenteuil. No further details received.'

If this is true, and I fear it is, I hasten to express my deep felt sorrow. I had hoped out friend's health had improved; that he had yet some years of life before him and that I should have the pleasure of meeting him at least once again. Now that can never be.

Great will be the grief of our lost friend's daughters and their families. I write to Madame Lafargue.

But for you! Yours is not an ordinary or a family loss. Your friendship and devotion, his affection and trust, made the fraternal connection of Karl Marx and Frederic Engels something beyond anything I have known of other men. That there was between you (two) a tie 'passing the love of woman' is but the truth. I seek in vain in words to express my sense of your bereavement, and my profound sympathy for and with your sorrow.

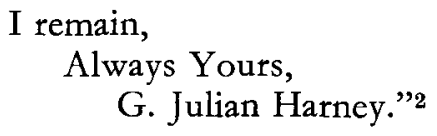

Harney next came to England in July I 884. He wrote to Engels on January 23 rd 1885 from 58 Bridge Street, Macclesfield: "For nearly two years a sufferer from miserable theumatism in America, I was, in a degree, better when I landed at Liverpool, beginning of July." 3 He mentioned that he was going to Cheltenham where he had some old Chartist friends. And then on May 3 Ist:

1 L IV I 85.

${ }^{2}$ L IV I 86.

${ }^{3} \mathrm{~L}$ IV ${ }_{1} 89$. 
"I have been puzzling my brains for the last three weeks to recall what I could have done to give me any claim to your hospitality and kindness, so much beyond anything I could have expected. But I cannot make it out. Your cheerful room, your good dinners, your wines, your cigars - these strike me not so much as your thoughtfulness in small things, your untiring kindness and anticipation of my wants in spite of the strain of your literary occupation. These and other evidences of a true friendship command and will continue to command my heartfelt gratitude.

My warm regards to 'Nim' - so unceasingly kind and untiringly good to me."1

In I 88 , Harney was in a bath chair with rheumatism in all his limbs, hands and feet. Increasingly his letters are taken up with his physical condition and his search for a cure. His political judgment, however, retains its discriminating, sceptical character:

"I am glad you retain some of your political enthusiasm and can yet feel some confidence in and hope of the English working classes. I daresay I too might have retained my 'youthful illusions' not much impared, if I had remained in England. But the long banishment of thirty years - including the Jersey sojourn - has made a difference. I doubt if in his old age Dante had left Ravenna for Florence he could have got up much steam in the way of admiration of, or trust in, his Florentine compatriots."2

On October 30 he told Engels that he proposed to return to America on January $13^{\text {th }}$ and commented on the London scene:

'The London 'Socialists' seemed to have scored a triumph over the East End police. But I have no belief in that 'Socialist' propaganda amongst such a population - too depressed, demoralised and degenerated by generations of pinching poverty. Poverty may stimulate some populations to heroic actions, but not the population of East or any part of London.

The General Election approaches and I suspect the 'Liberals' will carry the majority. But no parliamentary majorities will arrest the further decline in the condition of the workers. And a year or two hence with wages further beaten down and more thousands starving, the 'Liberals' may wish they had remained in opposition.

Slowly but surely Time is vindicating the action of the Chartists against the Manchester School and that School's hired agitators and journalists."

${ }^{1}$ L IV I 90.

L IV I92.

${ }^{3} \mathrm{~L}$ IV 194. In fact his departure was frequently postponed. He eventually sailed on the Gallic on October I 2 th I 886. L. IV 207. 
On December 24th 1885 he returned to the subject of Ireland:

"You and I probably are not of one mind on the Irish question, so I will only say I look upon Gladstone as a traitor. He was so in the Crimean War and in the last Russo-Turkish War. 'Everyman has price' and Gladstone his. I do not suppose he ever pocketed Russian gold, nor that he has lately received Irish-American gold. His price is the gratification of his vanity and of his lust for Power. These twin devils by which he is possessed will induce him to do anything. He should be handled without gloves as a traitor and public enemy."'

On February igth i 886, again from Macclesfield, Harney returned to the theme of Ireland:

“On 'Ireland and the Irish' we must agree, if we can agree at all - to differ, as for the present $\mathrm{Mr}$ Cowen and I do. I take my stand where the American unionists took theirs absolutely against all change intended to advance secession and dismemberment. I know the English, or rather the Normans, had 'no business' to go to Ireland - any more than the Franks had to invade Gaul, the 'Saxons' Britain and the Normans England. But I remember that an Irish Dilke invited the Norman English and a Pope consecrated the annexation. With Strongbow, Longbow and the rest of the Norman ruffians - and be damned to them! - I have no concern. I have to do with the now. What Ireland needs, and England too, is a Cromwell who should begin by hanging Parnell and his gang and Gladstone and Morley along with them; and then having executed justice on these ragamuffins, set about doing justice to - not only the 'farmers' but the labourers and others. At [the] same time remembering the Condition-of-England Question - and doing justice here as well as across the Channel.

Hyndman and Co have come to what I expected - or rather to their first stage only. 'Violent language' excited by the sight of misery I certainly could and would excuse - as long as addressed to bona fide working men (mechanics, labourers etc) but any encouragement addressed to the ruffianery of 'the East End', the wretches who do not plunder for food, but for pure cussedness can have no sympathy from me. Of the hordes rampaging along St James Street and Piccadilly, there were hundreds who would sell Hyndman himself for a gallon of beer. How can a man of his education and experience make such a fool of himself? Of course it will be great fun to get Gladstone, Chamberlain, Harcourt and Co into the witness box, if they can be got there. If the Judge says there is 'no case' against

${ }^{1}$ L IV I95. 
the accused, all right; but if he charges the Grand and Petty juries against them, they may expect no mercy, at least from the 'twelve men in a box'. The shopkeepers have been frightened and are thirsting for vengeance. See this week's Punch for an exhibition of 'middle-class' feeling.

A nice affair that of Dilke! I say nothing of the alleged offence. I suspect myself of a Dantean pity for sexual sins; but how villainous the conclusion. If Mrs Crawford guilty how could Dilke be innocent? If Dilke innocent what grounds for the judgment of 'guilty' against the wretched woman? I can only conclude that the Judge and the lawyers on both sides 'colloqued' to burlesque and outrage justice. And then the base Daily News and that wretched gang of miserable devils, the 'Liberals of Chelsea'! Any man who calls himself a Liberal is a knave or a fool."1

In August I 886 Harney was staying with Joseph Cowen at Stella Hall, Blaydon-on-Tyne. To Engels on the 23rd:

"I am sorry to know the Avelings are going to America. Pray urge caution upon them. After all the brag and bunkum, England is the true 'land of liberty' [...] In my judgment Dr and Mrs Aveling had better leave well alone and stay where they are." 2

Then writing of his own plans he said he was "thinking of going to my old 'happy (???) hunting ground' - Deptford and Greenwich - born in the former - three years at school in latter". ${ }^{3}$ Back in America he wrote about his plans to make a final return to England:

"My rheumatism has been about as bad as when with you in May 1885 and $I$ think $I$ have suffered more excruciating pain. I have been as wretched in mind as in body. But if $I$ live another 6 or 8 or 9 months, adieu for ever to this 'land of the free'. Mrs Harney (who thanks you for your remembrance) knows of my determination and must yield.

Mrs Harney met the Avelings."'4

On February 2nd i 887 he wrote to Engels to acknowledge receipt of two volumes of "Capital" and in his next letter on May 6th:

"I by no means take your favourable view of the Knights of Labour and similar organisations. In the first place their puerilities disgust me. Their 'dignities' make me feel sea-sick. Vanity and the love of notoriety are at the foundation of all these societies and organisa-

${ }^{1}$ L IV 197.

${ }^{2}$ L IV 200.

${ }^{3}$ L IV 20I, August 25th 1886.

4 L IV 205, November 19th 1886 from i6 Shepard Street, Cambridge, Massachusetts. Mrs Harney had not been with him on his last visit to England. She had been busy teaching. 
tions. A lot of fellows want to be Grand this and Grand that: Grand Dictator, Grand Chaplain, Grand doorkeeper, Grand Pisspot-emptier, Almighty Grand Panjandrum etc etc. A Yankee 'Sir Knight' makes me feel that I could - well, not need an emetic! Then my idea of these fellows is that they aim at establishing an Aristocracy of Labour in fact playing the rôle of that gang in London who are represented in Parliament by Broadhurst, Howell and Co., well held up by you to scorn.

Of Marx's great work I have read but little. Miserable and ceaseless pains of rheumatic gout hardly dispose one to the study of the dismal science even in its most inviting aspect. That review in the Athenaeum I thought very fair and very good, and likely to help the demand.

If you could only command reviews in the Quarterly and the Edinburgh no matter their time [?] or conclusions, such reviews would be of great advantage. Such must have mightily helped George, who has been the luckiest of agitators as George Washington was the luckiest of all recorded rebels. When the Quarterly and the Edinburgh deigned, 60-70 years ago, to notice Spence and his followers, they were spoken of as a sort of half-witted would-be thieves! In the distribution of 'monkeys allowances' Spence got the 'kicks', George all the 'half-pence'.'

Then on May I 3 th Harney wrote:

"I am sorry that you did not think of prefacing to Marx's great work a brief memoir or sketch of the life of the author. Had it been only two pages it would have been welcome and useful.

Don't write me purposely; but, if you think of it when you write, please say was Dr Marx born on 2nd or on sth of May I 8 I 8 ? I have both statements and it seems to me difficult for a man to be born on two distinct days - barring he's an Irishman."2

Next, on July i ith:

"Regarding the 'Jubilee' article, I am almost sorry you have sent it to Zurich, because of the damned misprints and the omissions. I send you, as regards the former, a corrected copy. My conclusion as to misprints is that they are one of the consequences of original sin. Of course I could not have been so idiotic as to have written in the reigns of Queen Anne'. Yet there it is, set up by the typo and allowed to pass by the 'reader' (corrector). There can be no salvation for printers.

The omissions were unavoidable - want of room. So Mr C. tells

1 L IV 207.

${ }^{2}$ L IV 208. 
me and I believe it. I had no thought of writing anything, but did so at $\mathrm{Mr}$ C's request on very short notice.

Amongst other matters the omissions included an estimate of the actual free press contrasted with what Hetherington and others hoped for - also [an] estimate of the new electorate. The omitted matter would have justified the pessimist tone of my concluding remarks.

In re the 'Knights of Labour' I daresay you are right as to crazyness in general. I have done some crazy things in my time; and, perhaps, even old as I am, might do some more if I had power and unfettered by my miserable infirmity.

I am glad you intend a biography of Marx. You are the only man to do it, and I trust you will yet find time and health for so important a work.

I remember Marx going to Carlsbad. Did it do him any good? Or did it abridge his days? Mrs $\mathrm{H}$. brought from the Library the other day a book about Carlsbad. But O! Lord! talk of the robber-knights of the Rhine! Faith! the Bohemians can match them. A cure-tax, even if you are not cured! A music-tax - though you may be fit for 'treasons, strategems and toils, have no music in your soul and care not a damn for their hurdy-gurdy performances! And then fees, fees on every hand, to headwaiters hand beadless waiters; and pay, pay for sneezing, coughing, winking! Carlsbad! Carlsdambad I should say; or, as the Germans are so fond of mighty long names, why not Carlsdamswindlingbad?"1

In August 1888 Harney was back in England again - this time only temporarily on his own - and staying once more at Macclesfield. Engels, however, had just done the crossing in the other direction and was staying with the Avelings in America. Harney wrote to him: "I am amused by your first impressions of Yankeeland 'a beautiful country to live - out of'. I thoroughly agree. Cannot Aveling get up a new piece: 'The Teuton in New York', with you for the hero?

I have been here six weeks and of that time not more than, if so many, as six tolerable days! I think the eternal bung's got loose and that poor old England is being drowned by all the drippings and dribblings from the entire solar system.",

Marie Harney came over to join her husband and they settled in at 27 St Mary Grove, Richmond-on-Thames. The correspondence immediately suffers from this proximity to Engels. Harney never left England again although Mrs Harney visited the US in $1892 .^{3}$

1 L IV 209.

${ }^{2}$ L IV 2 II.

${ }^{3}$ L IV 235 and 237. 


\section{V}

The 1892 exchange of letters has some of the old vigour. Harney wrote:

"I see another ministerial collapse in France, and the devil to pay everywhere. Is not Parliamentary Government an enormous humbug? Wanted a Dictator with the heart and consciene of Ruskin and the hand and brain of Cromwell."1

"I only once saw Bakunin, for a few minutes at the office of $\mathrm{La}$ Reforme early in March 1848 , (for like you he had returned). I thought he was a splendid looking man - almost a giant."2

"Saint Bismarck's Day. [...] I am glad I recalled to your memory the old sausage man. They were jolly times in Windmill Street. Time was then young - with us. But you - though your years increase - you do not grow old. Good. Long may you flourish."3

"I see in this day's N.D.C. notice of a police raid on The Commonweal. It is long since I saw a copy of that paper. I hope the Avelings have now nothing to do with it. I have no sympathy with Anarchists of any kind from Gladstone to Most. I have no wish to see an Anarchist Millenium."4

"Your first letter on European politics and the position of Russia very interesting. So also your second - regarding the Commonweal. Morris is like all poets who meddle with politics or great social questions - I except Byron in his last days. I do not except Shelley and Burns. Poets are of no account outside of their poetry - I mean in reference to public questions."5

"Your eternal youth is proved by your optimism; as my age is proved by my pessimism."6

"You are the Prince of Optimists. You always see the Universal Revolution just coming round the corner. My sight is not so good, nor my hope so sanguine. To me Trades Union and Socialist leaders appear very like other men - if no worse, no better."'?

${ }^{1}$ L IV 2 I9, February 21 th.

${ }^{2}$ L IV 220, March ist.

${ }^{3}$ L IV 224, April Ith.

${ }^{4} \mathrm{~L}$ IV 225, April 2oth.

${ }^{5}$ L IV 226, April 24th.

${ }^{6}$ L IV 227, May Ioth.

' L IV 237, July I4th. 
Engels was gratified at the return of the socialists John Burns and Keir Hardie to Parliament, and Harney replied on July 28th:

"I have nothing to object to your optimist reasons for belief in the good time coming. I hope you will experience no disappointment. As to the fruition of your labours - in the sense of triumphant ascendancy - you can hardly hope to see that. If you could, then would come the trial of your faith as then the conquering party would enter upon its real troubles, as was seen in the instances of the Provisional Government and the Commune.

However disappointment is the ordinary fortune of pioneers and by no means a sufficient reason for abstaining from pioneering.

I must say I cannot sufficiently admire the patience with [which] you treat your Pessimist friend. I am the more grateful for your enduring friendship."'

On the 4th February 1893 Engels wrote to Harney to suggest that he write a history of Chartism. Harney replied on the 24th:

"I have been aware of Wallas's intention for some time. If I were inclined to I could not prevent fulfilment of that intention - and as to anticipate him that would be impossible. A year ago, or more, I saw a prospectus - I think by Holyoake - of a course of lectures on Chartism by Wallas at the South Place Chapel, Finsbury. I suppose they were duly delivered. I saw my name for one item. What he had to say I do not know. I had information a year or more ago that he was ransacking at the British Museum, copying largely from manuscript books and albums of clippings, given to the B.M. by Francis Place - detested and riduculed by Cobbett under the name of 'Peter Thimble'. Probably Wallas would also ransack the Northern Star volume and other journals and books. I rather think, too, I was told that he employed persons to copy at the B.M. but of that I am not sure. I had a hint that he might call upon me to 'pump'; but so far, he has not been. I have heard of him travelling in the North to 'pick up' by interviewing 'Old Chartists' etc. I saw an account of him at Bradford. His old Chartists there must either have forgotten their Chartism in their Gladstonianism or be verging on their dotage - judging by their silly garrulity.

But Wallas, I suppose, is young, has money, can spend days at the B.M. without suffering; can travel etc etc. These advantages are denied me. Moreover there are other difficulties.

To say nothing of positive aches and pains, not the least of my troubles in inability to sleep naturally. Nights sleepless - or mainly 
sleepless - involve the distress of drowsiness during many hours of each day. In fact my 'working day' is as good as restricted to the hours between tea and bed - say from 6 to 12 p.m. though, in fact, I don't often get to bed at 12 . 'Eight hours!' I wish I could have 48 hours, or three parts of 48 for a working day. Many books, pamphlets, letters etc of mine are still in America - very necessary - but there seems but little prospect of my getting them. Lastly - though what I send to the N.W.C. does not involve much writing, it does much reading. If with all the drawbacks above indicated rather than enumerated, I should turn to the records of Chartism (unfortunately my Northern Stars are very incomplete and mostly wanting at the most important time 1838 -1839) I must give up my present writing for the N.W.C.

Now that present writing is a necessity. Little as it brings me it is necessary to supplement the little I get from America. I am not like Holyoake with his annuity - or Gerald Massey with his pension or the late Thomas Cooper who practically had his annuity with ability to command other help. I know what could be done; but it is not offered, nor likely to be that I see. I speak not of this, but of another part of the country. So I don't see my way.

You speak of a 'publisher'. I promised, a considerable time ago, that if I ever wrote anything on the theme you suggest, I would send, in the first instance, to the N.W.C. When I say I promised, I did so to the Editor W. E. Adams, not to the proprietor Mr. C.

You may naturally say 'Well, if you must write weekly, why not, at least for a time, write on "Chartism» instead of on "Books" or current topics?' But I could not do that, I would not begin without some weeks of preparation and at least a few chapters, or sections got ready in advance.

So you see, I remain in doubt and indecision. And what comes of that I know, just as well as you could tell me - Nothingness and death. 'Tis true, 'tis pity, and pity 'tis, 'tis true.' [...]

This I feel is a very unsatisfactory letter and I regret it; but I am obliged by your kind suggestions and remain, Yours ever, G. Julian Harney."1

Engels wrote to Harney with some enthusiasm on the subject of the socialists of Germany. Harney was unrelenting:

"I have not the least confidence or belief in the class toward whose political and social emancipation I gave the best years of my life.

It is hardly to be hoped for, though it may be, that you will

${ }^{1}$ L IV 247. The N.W.C. was the Newcastle Weekly Chronicle owned by the same Joseph Cowen that Harney had met in his Chartist days. 
witness and share in the first acknowledged victory of socialist ascendancy in Germany. I hope you may, because as the Nestor of Socialism your lengthy and matchless experience will enable you to proffer counsels of wisdom which if followed may save the Social Revolution from the shipwreck suffered by the Political Revolution in 1848 .

I am glad your long voyage with Marx's 'Capital' is nearly ended. You see land. And I trust the completion of your great labour will add a new and intensified zest to your next Christmas festivities.

Never, I think, at least in modern times, has any man found so faithful, so devoted a friend and champion as Marx has found in you. We much regret, at least I may, that Marx is not with us to express his appreciation of such gallant service."1

Following what Harney had had to say about his own personal circumstances and the writing of the history of Chartism, Engels then took, or proposed to take, some personal initiative in this connection. Harney wrote back:

"I cannot sufficiently express my grateful sense of your (by me) unsolicited, unthought of service in seeking the help you indicate [...] Had it been successful I could not have agreed to any such arrangement. I would not have accepted money in advance for work which - notwithstanding the best and most earnest intentions on my part - might never have been performed [...]

I think it might have been rendered in a certain quarter without any appreciable sacrifice - I giving some and honourable equivalent, but it has not been, and, as far as I can see, is not likely to be offered."2

In February I 894 Harney recalled how he learnt of the February Revolution in France:

"I am glad you accepted and like the photo.

The old time! And this is the 23 rd of February and tomorrow the 24th. When seeing the news placarded at Charing Cross I ran like a lunatic and pulled the bell at Schapper's like a bedlamite; at some corner, on my way, knocking over an old woman's applebasket (or it may have been oranges!). I was going too quick to hear her gentle cursing. I could 'go' on my legs then! And then believed, what, alas! to my bitter sorrow, I cannot believe now - believed in 'the sovereign people'."3

2 Also L IV 248.

${ }^{3}$ L IV 254. 
It is fitting that the correspondence ends in a blaze of uncompromising argument about essentials - an argument at the same time conducted in terms of the utmost personal goodwill and affection. On July 3 rd I 894 Harney wrote to Engels :

"I am sorry your men in Berlin made a kind of apology for Santo - or tried to lay the blame of his crime on present society. That kind of thing will not help socialism. There can be no truce with Thugs and they are not to be whitewashed by any diatribes against 'bourgeois society'. I see that a journalist has been stabbed to death at Leghorn. Do your men in Berlin justify or excuse that? Nice 'Liberty of the Press' under 'Anarchism'."I

Then, two days later, on the same subject:

"Regarding the murder of President Carnot, the 'Times' etc. I hope I am still as much the enemy of 'his', 'bloody' or other, as in the days of the Northern Star. My reference was to a statement to the effect that the Berlin socialist newspaper, the Vorwärts, had published an article 'in which there was not a word of reprobation for the assassin, and scarcely a word of sympathy for his victim beyond the grudging admission that he was personally an honourable man, which it, moreover promptly qualified by adding that he was a typical bourgeois from the crown of his head to the soles of his feet. In fact it did not hesitate to say that by ratifying the death sentence passed on a madman like Henry he cast a dark shadow on his name.' And so on.

I do not see the daily issue I see only the weekly issue of the Times. The fuller statement will be found on the second page of the weekly of June 29th.

If there are lies in the statement - if the statement misrepresents the Vorwärts, a contradiction should have been published. If you say the statement is lies I will on your authority send a contradiction to the Times - failing publication, I will ask publicity for it in the Newcastle Chronicle, daily and weekly.

The statement immediately followed one relating to Louise Michel. If her ravings are truly stated she should be consigned to a Lunatic Asylum.

If the Times statement falsified the Vorwärts why was not the lie at once treated like a bad shilling nailed to the counter?

If the Anarchist paper in Berlin, the 'Socialist', can be proved to be in the pay of the Police, why not proclaim the fact? Has anyone published that Ravachol was at one time in the pay of the police?

${ }^{1}$ L IV 256. 
If he was what is to be thought of those who treasure his portrait and his memory as a 'martyr'?

I do not follow your argument or your utterances as to the murdered president. He may have been 'dull', 'melancholy' and 'an awfully correct' specimen of 'middle-class respectability' but hardly deserved death. Are all the 'dull' people to be killed? That might please the Neo-Malthusians and go some way toward a solution of the Labour question by reducing or extirpating the 'surplus'. But the 'dull' might very reasonably object. Whether a man is middle class, or working class, or aristocratic class, I have no objection to him on the ground that he is 'awfully correct'; better be 'awfully correct' than an awful blackguard. Murder is murder whether the victim be Mrs. Rasch or President Carnot and in each case the murderer should be effaced. But the one was a commonplace murder affecting less than a dozen persons, the other a murder affecting a nation. You may say 'No! - affecting bourgeois society!' I cannot see the distinction.

He (Carnot) was the elect of the Chambers, but the Chambers were the elect of Universal Suffrage. If bourgeois society is hateful to the French why does not Universal Suffrage overthrow it? If Carnot was 'dull', why did not the Chambers elect a brilliant man? Brilliant men - whatever their moral qualities - have never been wanting in France, and never will be, that characteristic belongs to the race. But are brilliant men always the most desirable as rulers? That depends! Had Carnot been brilliant, assertive and aggressive - as your brilliant men are apt to be - he would have been denounced as aiming at or practising 'personal government'; and that, I suppose, by some people would have been held to justify Santo's dagger. So the President of the French Republic seems to be between the devil and the deep sea - doomed if brilliant, and not to be pitied if dull.

I hope I can as warmly as any sympathise with and deplore the deaths of the miners in Wales and Austria; but as regards 'capitalist greed', suppose the mines declared national property and taken over by the Governments, would that prevent explosions? Of the Austrian Government and Parliament I know, I may say, nothing; but poor as is my opinion of the British, I think that both Government and Parliament would hasten to adopt and enforce any measures science could devise as adequate to prevent mining disasters. As to 'Eight Hours' simply - I suppose that could hardly be counted upon as a sufficient preventive and safeguard.

I have written reluctantly and more than I intended, for I hate to even seem to differ from you. Perhaps I am too 'dull' to understand 
and appreciate the ethics of modern revolutionaries; but I am not so old as to have forgotten the beginning of our long continued friendship, nor so dull as not to appreciate the sterling and brilliant qualities of Karl Marx's Fidus Achates."1

Engels must have replied at length and by return. Harney's next letter is dated July $9^{\text {th }}$ :

"I am sorry to have occasioned such an expenditure of your time as your last letter implies. Continuation of correspondence on so unsavoury a subject as the Anarchists is not desirable, nor could it be of any use inasmuch as you and I see through different 'glasses'. I would rather see you through a glass of good Rhine wine, or even 'Scotch' or 'Irish'.

It seems to me no men can be more interested than the Socialists in stamping out Anarchism - for to condone, excuse or palliate the atrocities of the Anarchists now is to prepare a danger for the Socialists in the future - that is the Socialists are to be supreme in the future, as you believe they will be. The first day of the supremacy will be the first day of trouble far more serious than Bismarckian prosecutions and persecutions. Factions now united 'against the common enemy' will soon show themselves when the future is to be regulated. If the Anarchists continue until then their 'game' will not be princes and presidents and prime-ministers, but leaders of the new system not prepared to give way to anarchist madness. Then if crime is committed it will be laid to the account of the new Socialistic society, as it is now laid to the account of Bourgeois society.

I see no reason to contest your allegations as to the 'greed' of the Capitalist class. I think that applies to all classes. When Newcastle engineers or Federation miners go out on strike they never ask who outside their ranks will be injured; they never consider the thousands who will be deprived of employment who have no share in their grievances. What cared they when the miserable poor of Bermondsey and Bethnal Green had to pay $2 /$ - for a cwt. of coal or go fireless. I grant you the capitalists are selfish, but so are all other classes. Least of all have I any belief in Trades Union chiefs and Labour leaders. To not one of them at present before the public would I give a vote $[\ldots]$

Much more might be said but cui bono? Let us agree to differ, if we cannot have more pleasant agreement."'2 
The last surviving letter written by Harney to Engels is dated January 3 rd 1895 :

"You have done with the Marx work, but there is plenty more to do! What a glutton you are! What about the eight hours? Can we wonder at the number of unemployed when you take in hand the work of half-a-dozen men, and then like Hotspur (after killing half-a-dozen Scots before breakfast by way of getting up an appetite for his caller herrin') you cry "Fie! upon this idle life!"1

Harney outlived Engels by two years and died on December 9 th I 897 . Like Engels he went on working to the end. Bedridden, he dictated his last articles to a friend. In February 1897 , at a presentation in his honour on the occasion of his 8oth birthday, he had looked back over the years of struggle for the Charter:

"It may be said that the Chartist agitation - which had for its object the reform of Parliaments - was so much energy wasted. I think not. The Chartist influence extended beyond the Six Points, and to it we largely owe the extirpation of innumerable, some of them abominable, abuses, and a great widening of the bounds of freedom. I do not attach supreme importance to any form of government. All forms have had their uses and merits at particular times. But all have failed to bringus even near to that perfectibility of man, which was the beautifuldream of so many good men and somany eloquent writers a little over a hundred years ago."'2 With that Engels might have been in substantial agreement.

1 L IV 260. "Caller herrin" means "fresh herrings" in the dialect of Northumberland.

2 Schoyen, op. cit., p. 285. 